\title{
Anonyme data og forskningsetikk
}

Du er psykiater og forsker på seksuelle overgrep og mental helse. I prosjektet skal du videreutvikle et amerikansk kartleggingsskjema og validere dette for klinisk bruk. Som en pilotstudie, og for å få normaldata, deler du ut spørreskjemaet til studentene dine i begynnelsen av en forelesning og ber dem levere en anonym besvarelse. Skal du da søke regional etisk komité?

Min erfaring er at mange tror at forskning på anonyme data kan gjøres uten krav om REK-godkjenning eller andre godkjenninger. Dette er en begrenset sannhet som avhenger av flere forhold.

Norsk medisinsk og helsefaglig forskning er regulert av helseforskningsloven, som stiller krav om at alle prosjekter på helseopplysninger, humant biologisk materiale eller mennesker skal forhåndsgodkjennes av regional etisk komité. Det holder at studien involverer én av de tre kategoriene.

Helseopplysninger: Helseopplysninger kan knyttes til enkeltperson, enten direkte eller via en koblingsnøkkel. Opplysninger som ikke lenger kan knyttes til en enkeltperson, er anonyme og kan i utgangspunktet benyttes fritt.

Humant biologisk materiale: For humant biologisk materiale har lovgiver lagt til grunn at dette har større beskyttelsesbehov enn helseopplysninger og at det kan være vanskelig eller umulig å anonymisere materialet fullstendig. Derfor kreves REK-godkjenning også for bruk av såkalt anonymt materiale, men naturlig nok ikke samtykke, da dette ikke lar seg innhente uten å reidentifisere donor. Prospektiv innhenting av forskningsmateriale fra person for umiddelbar eller fremtidig anonymisering vil imidlertid kreve både REKgodkjenning og samtykke, jf. helseforskningsloven $\S 20$.

På mennesker: Selv om opplysningene som brukes er anonyme, kan studien være fremleggelsespliktig for regional etisk komité hvis den innebærer forskning på mennesker. Lovverket definerer dette slik: «Med forskning på mennesker siktes det i første rekke til forskning som direkte involverer mennesker (forskningsdeltakere) på en eller annen måte, for eksempel ved at forskerne har direkte kontakt med deltakeren, jf. lovens kapittel 5» (1). Dette kan forstås både som forskning der forsker og informant har direkte kontakt og som annen intervensjonsforskning der deltakelsen kan innebære risiko eller ulempe for deltakeren.

Det gjennomføres et stort antall spørreundersøkelser der forskere leverer ut eller postlegger skjemaer med oppfordring om at informantene besvarer undersøkelsen anonymt. I slike tilfeller vil det være varierende grad av kontakt mellom forsker og informant. Det kan være uklart om det skal regnes som forskning på mennesker og om studien dermed er fremleggelsespliktig for regional etisk komité.

I en artikkel i Forskningsetikk tar Sigmund Simonsen og undertegnede til orde for at direkte utdeling av spørreskjemaer, som i det innledende eksemplet, som hovedregel vil regnes som forskning på mennesker, uavhengig av om de data som samles inn, er personidentifiserbare eller anonyme (2). Men hva om spørreskjemaene sendes per post eller bare legges ut i det offentlige rom slik at inter- esserte kan plukke dem opp? Da er det ikke lenger noen direkte kontakt mellom forsker og informant. Det vesentlige da blir om spørreskjemaet på grunn av sitt innhold likevel skal betraktes som en intervensjon og derfor regnes som forskning på mennesker.

Slike spørreskjemaundersøkelser representerer ulik grad av belastning for informantene. Noen undersøkelser vil åpenbart kunne være belastende for enkelte, da de kan omhandle forhold som angst, suicidalitet, overgrep, mobbing osv. For slike prosjekter vil en forhåndsvurdering fra regional etisk komité kunne være positivt for å sikre at studien er legitim og forsvarlig og at det finnes prosedyre for oppfølging og hjelp til informanter som skulle få behov for dette.

Det finnes ikke et enkelt enten-eller-svar på fremleggelsesplikt når det gjelder studier som innebærer innsamling av anonyme data. Forskeren må selv gjøre en konkret vurdering i hvert enkelt tilfelle. Konteksten er avgjørende - for eksempel grad av kontakt mellom forsker og deltaker, type data som innhentes, innsamlingsprosedyre, sensitivitet/tema, deltakergruppe og om anonymiteten er reell. Hvis studien innebærer direkte kontakt mellom forsker og informant eller er av en type som trolig innebærer vesentlig belastning for informantene, bør forsker kontakte regional etisk komité for en vurdering av fremleggelsesplikten før prosjektstart. Dette kan gjøres via REK-skjemaet for fremleggingsvurdering (3). Dette er en rask og enkel prosedyre som også har den fordel at forskeren kan dokumentere at regional etisk komité er konsultert hvis det blir spørsmål $i$ ettertid. Endelig bør det understrekes at selv om prosjektet ikke vurderes som fremleggelsespliktig for regional etisk komité, vil tillatelse fra andre instanser kunne være nødvendig, det gjelder for eksempel personvernombudet eller Datatilsynet.

\section{Jacob C. Hølen}

jacob.holen@etikkom.no

Jacob C. Hølen (f. 1975) er ph.d., sekretariatsleder i Den nasjonale forskningsetiske komité for medisin og helsefag (NEM) og førsteamanuensis ॥ ved Institutt for samfunnsmedisin, Norges teknisk-naturvitenskapelige universitet

Forfatter har fylt ut ICMJE-skjemaet og oppgir ingen interessekonflikter

\section{Litteratur}

1. Ot.prp. nr. 74 (2006-2007), s. 148. Om lov om medisinsk og helsefaglig forskning (helseforskningsloven). www.regjeringen.no/nb/dokumenter/otprp-nr-74-20062007-/id474780/ (12.4.2015).

2. Simonsen S, Hølen J. Er forskningsprosjekter med innsamling av anonyme data å anse som forskning på mennesker? Forskningsetikk 2010; 10: 22-23. www.etikkom.no/Aktuelt/Fagbladet-Forskningsetikk/arkiv/2010/2010-1/Debatt/ (12.4.2015).

3. REK. Regionale komiteer for medisinsk og helsefaglig forskningsetikk. Framleggingsvurdering. https://helseforskning.etikkom.no/ikbViewer/page/frister/ forskningsprosjekt/framleggingsvurdering?p_dim $=34769 \&$ ikbLanguage Code=n (12.4.2015). 